УАК 332.3:347.255

ФОРМУВАННЯ ТА ОБЛІК

ВЛАСНОГО КАПІТАЛУ В TOВАРИСТВАХ 3

ОБМЕЖЕНОЮ

ВІДПОВІДАЛЬНІСТЮ: СТАН НОРМАТИВНО-ПРАВОВОГО ВРЕГУЛЮВАННЯ ${ }^{\odot}$

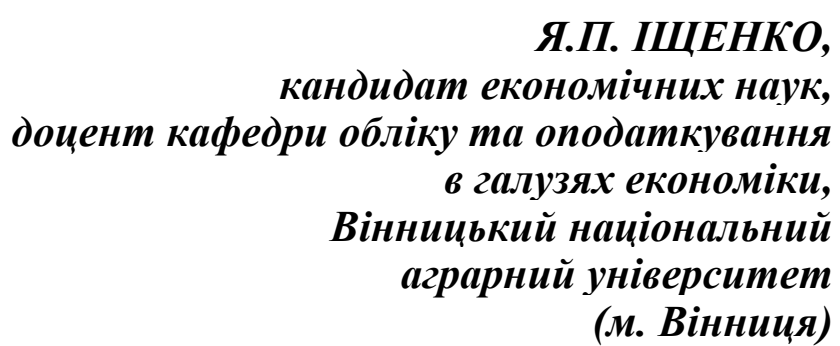

(м. Вінниця)

Публікачія присвячена вирішенню проблеми належного правового забезпечення та розкриття інформачії про операчії з власним капіталом у системі бухгалтерського обліку аграрних підприємств. На основі дослідження нормативноправових актів узагальнено існуючі підходи до визначення поняття «власний капітал». Розглядається нормативне регулювання формування власного капіталу та його обліку на макро- та мікрорівнях в товариствах з обмеженою відповідальністю, як однієї з найпоширеніших організачійно-правових форм підприємств, щуо функиіонують в аграрному секторі економіки. Окреслено зміни регулювання діяльності товариств з обмеженою відповідальністю згідно з Законом Украӥни «Про товариства 3 обмеженою та додатковою відповідальністю» від 06.02.2018p. №2275-VIII, щзо призводять до необхідності внесення змін до установчих документів та внутрішніх регламентів обліку.

Запропоновано елементи організачійної та методичної складової облікової політики щчодо власного капіталу, щзо дозволить узгодити положення облікової політики та установчих документів з метою задоволення інтересів користувачів щзодо інформації про власний капітал. Розроблено розділ наказу про облікову політику, щцо регулюватиме облік власного капіталу в товариствах з обмеженою відповідальністю.

Ключові слова: власний капітал, статутний капітал, товариства 3 обмеженою відповідальністю, облікова політика, статут, правове регулювання, облік, звітність.

Табл.: 3. Рис.: 1. Літ.: 12.

\title{
REGULATORY FORMATION AND ACCOUNTING OF EQUITY AT LIMITED LIABILITY COMPANIES
}

\section{ISHCHENKO Ya., Candidate of Economic Sciences, Associate Professor of the Department of Accounting and Taxation in the Sectors of the Economy, Vinnytsia National Agrarian University (Vinnytsia)}

The publication is devoted to solving the problem of proper legal provision and disclosure of information on transactions with equity capital in the accounting system of agrarian enterprises. On the basis of the study of normative legal acts, the existing 


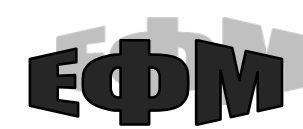

http://efm.vsau.org/

approaches to the definition of "equity" are generalized. The normative regulation of formation of own capital and its accounting at macro and micro levels in limited liability companies is considered. The changes in the regulation of activity of limited liability companies are outlined in accordance with the Law of Ukraine "On Limited Liability Companies" of 02.06.2018 No. 2275-VIII, which causes the need to amend the constituent documents and internal accounting regulations.

The elements of organizational and methodical component of the accounting policy concerning equity capital are proposed, which will allow to reconcile the provisions of the accounting policy and constituent documents. An example section of the order on accounting policies that regulates the accounting of equity capital in limited liability companies is developed.

Key words: equity capital, authorized capital, limited liability companies, accounting policy, statute, legal regulation, accounting, reporting.

Tabl.: 3. Fig.: 1. Ref.: 12.

\title{
НОРМАТИВНОЕ РЕГУЛИРОВАНИЕ ФОРМИРОВАНИЯ И УЧЁТА СОБСТВЕННОГО КАПИТАЛА В ОБЩЕСТВАХ С ОГРАНИЧЕННОЙ ОТВЕТСТВЕННОСТЬЮ
}

\author{
ИЩЕНКО Яна Петровна, \\ кандидат экономических наук, \\ доцент кафедры учета и \\ налогообложения в отраслях экономики, \\ Винницкий национальный аграрный университет
} (2. Винница)

Публикащия посвящена решению проблемы надлежащего правового обеспечения и раскрытия информаџии об операщиях с собственным капиталом в системе бухгалтерского учёта аграрных предприятий. На основе исследования нормативно-правовых актов обобщены существующие подходы к определению понятия «собственный капитал». Рассматривается нормативное регулирование формирования собственного капитала и его учёта на макро- и микроуровне в обществах с ограниченной ответственностью как одной из самых распространенных организационно-правовых форм предприятий, функиионирующих в аграрном секторе экономики. Определены изменения регулирования деятельности обществ с ограниченной ответственностью в соответствии с Законом Украинь «Об обществах с ограниченной $и$ дополнительной ответственностью» от 06.02.2018p. №2275-VIII, которые обуславливают необходимость внесения изменений в учредительные документы и внутренние регламенты учёта.

Предложены элементы организационной и методической составляющей учетной политики в отношении собственного капитала, что позволит согласовать положения учетной политики и учредительных документов, с иелью удовлетворения интересов пользователей по информации о собственном капитале. Разработан примерный раздел приказа об учётной политике, регулирующего учёт собственного капитала в обществах с ограниченной ответственностью.

Ключевые слова: собственный капитал, уставный капитал, общества с ограниченной ответственностью, учётная политика, устав, правовое регулирование, учёт, отчетность.

Табл.: 3. Рис.: 1. Лит.: 12. 


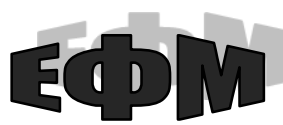

http://efm.vsau.org/

Постановка проблеми. Структура і динаміка власного капіталу є основою для визначення показників, що характеризують фінансовий стан та фінансову стійкість підприємства. Інформаційне забезпечення для ефективного управління власним капіталом підприємства формується, в основному, системою бухгалтерського обліку та фінансової звітності.

Достовірне та повне висвітлення у фінансовій звітності інформації про розмір та склад власного капіталу є принциповим для об'єктивної оцінки фінансового стану та ефективності діяльності підприємства та для прийняття подальших рішень власниками, інвесторами, кредиторами та іншими користувачами інформації.

Протягом останніх років внесені певні зміни в порядок відображення в обліку власного капіталу товариств 3 обмеженою відповідальністю, що потребує детального аналізу і оцінки змін для свого удосконалення. Цим аспектам присвячено зазначену статтю.

Аналіз останніх досліджень і публікацій. Проблеми ефективного управління підприємствами аграрного сектору економіки різних організаційно-правових форм розглядались в працях провідних вітчизняних науковців, зокрема Г.М. Калетніка [1], В.А. Мазура [2]. Проблемам обліку формування та використання власного капіталу присвячені праці таких вчених, як Н.М. Гудзенко [3], В.М. Жук, Н.Г. Здирко [4], Т.Г. Камінська [5], Л.В. Коваль [6] та ін. Проте з прийняттям Законів «Про внесення змін до Закону України «Про бухгалтерський облік та фінансову звітність в Україні» щодо удосконалення деяких положень» від 05.10.2017 р. [7] та «Про товариства 3 обмеженою та додатковою відповідальністю» від 06.02.2018 p [8] змінились вимоги до формування власного капіталу та відображення його в обліку і фінансовій звітності в напрямку наближення до міжнародної практики та до вимог міжнародних стандартів обліку. Це потребує детального аналізу і оцінки змін, що відбулися в правовому полі, виокремлення існуючих проблем обліку власного капіталу та пошуку шляхів його удосконалення.

Формулювання цілей статті. Відтак метою даної публікації є дослідження правового регулювання формування та обліку власного капіталу, зокрема в товариствах з обмеженою відповідальністю.

Виклад основного матеріалу дослідження. Господарські товариства $\epsilon$ однією з поширених організаційно-правових форм господарювання в аграрному секторі економіки України (табл. 1).

У 2017 p. 345558 суб'єктів господарювання, що провадили сільськогосподарську діяльність, 6967 мали статус господарських товариств. Це більше 15\% від загальної кількості підприємств. При цьому у користуванні товариств перебувало 14,3 млн га земель сільськогосподарського призначення, що становить 46\% площі сільськогосподарських земель, що перебувають у приватній власності [9].

Згідно зі ст. 113 Господарського кодексу України, господарським товариством $\epsilon$ юридична особа, статутний капітал якої поділений на частки між учасниками. Господарські товариства можуть бути створені у формі повного товариства, командитного товариства, товариства 3 обмеженою або додатковою відповідальністю, акціонерного товариства.

Господарський кодекс України визначає товариство 3 обмеженою відповідальністю, як господарське товариство, що має статутний капітал, поділений на частки, розмір яких визначається установчими документами, i несе 
відповідальність за своїми зобов'язаннями тільки своїм майном. Учасники товариства, які повністю сплатили свої вклади, несуть ризик збитків, пов'язаних 3 діяльністю товариства, у межах своїх вкладів [10].

Таблиияя 1

Кількість підприємств України, які здійснювали сільськогосподарську діяльність за організаційно-правовими формами господарювання

\begin{tabular}{|c|c|c|c|c|c|c|}
\hline \multirow{2}{*}{$\begin{array}{c}\text { Організаційно-правові форми } \\
\text { господарювання }\end{array}$} & \multicolumn{6}{|c|}{ Роки } \\
\hline & 2012 & 2013 & 2014 & 2015 & 2016 & 2017 \\
\hline Усього & 49415 & 49046 & 46199 & 45379 & 47697 & 45558 \\
\hline Господарські товариства & 8235 & 8245 & 7750 & 7721 & 8700 & 6967 \\
\hline Приватні підприємства & 4220 & 4095 & 3772 & 3627 & 3752 & 3215 \\
\hline Кооперативи & 848 & 809 & 674 & 596 & 738 & 448 \\
\hline Фермерські господарства & 34035 & 34168 & 33084 & 32303 & 33682 & 34137 \\
\hline Державні підприємства & 296 & 269 & 228 & 241 & 222 & 199 \\
\hline $\begin{array}{l}\text { Підприємства інших форм } \\
\text { господарювання }\end{array}$ & 1781 & 1460 & 691 & 891 & 603 & 592 \\
\hline \multicolumn{7}{|c|}{ У відсотках до підсумку } \\
\hline Усього & 100,0 & 100,0 & 100,0 & $\mathbf{1 0 0 , 0}$ & $\mathbf{1 0 0 , 0}$ & 100,0 \\
\hline Господарські товариства & 16,7 & 16,8 & 16,8 & 17,0 & 18,2 & 15,3 \\
\hline Приватні підприємства & 8,5 & 8,3 & 8,2 & 8,0 & 7,9 & 7,1 \\
\hline Кооперативи & 1,7 & 1,6 & 1,4 & 1,3 & 1,5 & 1,0 \\
\hline Фермерські господарства & 68,9 & 69,7 & 71,6 & 71,2 & 70,6 & 74,9 \\
\hline Державні підприємства & 0,6 & 0,6 & 0,5 & 0,5 & 0,5 & 0,4 \\
\hline $\begin{array}{l}\text { Підприємства інших форм } \\
\text { господарювання }\end{array}$ & 3,6 & 3,0 & 1,5 & 2,0 & 1,3 & 1,3 \\
\hline
\end{tabular}

Джерело: [9]

Від повного та чіткого правового регулювання обліку власного капіталу підприємствами різних організаційно-правових форм безпосередньо залежить ефективність інформаційного забезпечення управління про формування капіталу, розподіл прибутку, нарахування дивідендів та інших корпоративних прав, фінансову незалежність діяльності підприємства та інші показники фінансового стану.

Нормативне регулювання обліку власного капіталу в Україні здійснюється на рівні держави (макрорівень) та на рівні суб'єктів господарювання (мікрорівень) (табл. 2).

Основними законодавчими актами макрорівня є кодекси та Закони України, національні положення (стандарти) бухгалтерського обліку щодо власного капіталу.

Порядок формування власного капіталу підприємствами різних організаційноправових форм визначено Господарським та Цивільним кодексами України.

Методологічні засади формування в бухгалтерському обліку інформації про власний капітал та розкриття такої інформації у фінансовій звітності визначається НП(С)БО 1 «Загальні вимоги до фінансової звітності». Даний Стандарт визначає зміст поняття «власний капітал», зміст і форму Звіту про власний капітал та загальні вимоги до розкриття його статей [11].

Згідно з НП(С)БО 1, власний капітал - частина в активах підприємства, що залишається після вирахування його зобов'язань. Таке визначення $є$ практично ідентичним 3 визначенням власного капіталу у міжнародних стандартах. У 
Концептуальній основі фінансової звітності власний капітал визначається, як частка в активах підприємства, яка залишається після того, як будуть погашені всі його зобов'язання [12].

Таблиия 2

Рівні нормативного регулювання обліку власного капіталу

\begin{tabular}{|c|c|}
\hline $\begin{array}{c}\text { Рівні } \\
\text { регулювання }\end{array}$ & Нормативні акти \\
\hline \multirow{9}{*}{ 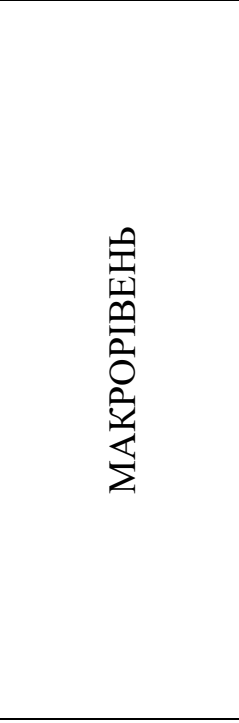 } & Господарський кодекс України від 16 січня 2003 року № 436-IV \\
\hline & Цивільний кодекс України від 19.06.2003 р. № 980-IV \\
\hline & Податковий кодекс України від 2 грудня 2010 року №2755-VI \\
\hline & $\begin{array}{l}\text { Про бухгалтерський облік та фінансову звітність: Закон України } \\
\text { затверджений Верховною Радою України від 11.05.2000 p. №1707-III }\end{array}$ \\
\hline & $\begin{array}{l}\text { Про товариства з обмеженою та додатковою відповідальністю: Закон України } \\
\text { від 06.02.2018 №2275-VIII }\end{array}$ \\
\hline & Про акціонерні товариства: Закон України від 17.09.2008 №514-VI \\
\hline & $\begin{array}{l}\text { Про інвестиційну діяльність: Закон України, затверджений Верховною Радою } \\
\text { України від 18.09.1991 №1560-XII. }\end{array}$ \\
\hline & $\begin{array}{l}\text { Національне положення (стандарт) бухгалтерського обліку } 1 \text { «Загальні } \\
\text { вимоги до фінансової звітності», затверджене наказом Міністерства фінансів } \\
\text { України від } 07 \text { лютого } 2013 \text { року № } 73 \text {. }\end{array}$ \\
\hline & $\begin{array}{l}\text { План рахунків бухгалтерського обліку, активів, капіталу, зобов'язань і } \\
\text { господарських операцій підприємств і організацій: Затверджено наказом } \\
\text { Міністерством фінансів від 30.11.99p. №291. }\end{array}$ \\
\hline \multirow{2}{*}{ 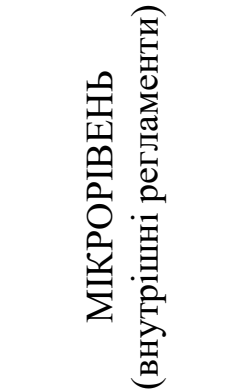 } & Статут підприємства, засновницький договір \\
\hline & $\begin{array}{l}\text { Наказ (положення) про облікову політику, план-графік документообігу, } \\
\text { робочий план рахунків }\end{array}$ \\
\hline
\end{tabular}

Загалом міжнародні стандарти бухгалтерського обліку та фінансової звітності не здійснюють детального регулювання обліку власного капіталу. Це зумовлюється специфікою законодавства різних країн щодо формування власного капіталу підприємств різних організаційно-правових форм.

З 17.06.2018 р. набрав чинності Закон України «Про товариства з обмеженою та додатковою відповідальністю» [8]. Кардинальна зміна регулювання діяльності господарюючих суб'єктів таких організаційно-правових форм призводить до необхідності внесення змін до його установчих документів та внутрішніх регламентів обліку.

Відповідно до зазначеного Закону, значні зміни стосуються формування статутного капіталу товариств з обмеженою та додатковою відповідальністю:

по-перше, не обмежується кількість учасників товариства. До цього кількість учасників ТОВ та ТДВ була обмежена кількістю у 100 осіб;

по-друге, статутний капітал має бути сформований у повному обсязі (в сумі, зареєстрованій в установчих документах) не пізніше 6 місяців 3 дня державної 
реєстрації товариства (інший строк може бути передбачений статутом при одностайному рішенні загальних зборів);

по-третє, вартість вкладу кожного учасника товариства повинна бути не менше номінальної вартості його частки.

Вклади учасників у негрошовій формі оцінюються за справедливою вартістю, що затверджується одностайним рішенням загальних зборів учасників, у яких взяли участь всі учасники товариства.

Про прострочення внесення вкладів учаснику (учасникам) надсилається письмове попередження, після чого учасник може погасити заборгованість протягом 30 календарних днів. Після завершення цього терміну загальні збори учасників мають прийняти одне з таких рішень:

1) про виключення учасника товариства, який має заборгованість із внесення вкладу;

2) про зменшення статутного капіталу товариства на розмір неоплаченої частини частки учасника товариства;

3) про перерозподіл неоплаченої частки (частини частки) між іншими учасниками товариства без зміни розміру статутного капіталу товариства та сплату такої заборгованості відповідними учасниками;

4) про ліквідацію товариства [8].

При цьому учаснику, який повністю або частково не вніс свій вклад, товариство не має права виплачувати дивіденди.

У Законі «Про товариства 3 обмеженою та додатковою відповідальністю» передбачено можливість збільшення розміру статутного капіталу за рахунок нерозподіленого прибутку товариства за умови, що склад учасників та співвідношення розмірів їхніх часток у статутному капіталі не змінюються.

Про рішення загальних зборів учасників щодо зменшення розміру статутного капіталу товариство повинно повідомити письмово (не пізніше 10-денного строку 3 дня його прийняття) кредиторів. Повідомлення надсилається не всім кредиторам (як це було раніше), а лише тим, чиї вимоги не забезпечені заставою, гарантією чи порукою.

Важливим нововведенням до регулювання власного капіталу ТОВ є те, що частку учасника можна відчужити або передати в заставу.

Відповідно до перерахованих змін у чинному законодавстві, товариствам 3 обмеженою відповідальністю необхідно до 18.06.2019 р. внести зміни до Статутів.

На рівні підприємства, крім Статуту та корпоративного договору (складання якого передбачене Законом про ТОВ та ТДВ) щодо власного капіталу, має бути сформована облікова політика. Фіксується облікова політика у відповідному внутрішньому регламенті: положенні чи наказі про облікову політику. Частіше товариства 3 обмеженою відповідальністю формують відповідні накази. Стосовно організації обліку власного капіталу та методики відображення операцій з ним в цьому наказі слід відобразити наступні норми (рис. 1).

Як показало дослідження практики формування облікової політики товариств 3 обмеженою відповідальністю Вінницької області, що здійснюють господарську діяльність в аграрній сфері, норми їх облікової політики щодо власного капіталу врегульовані у внутрішніх регламентах лише в наступних моментах: 


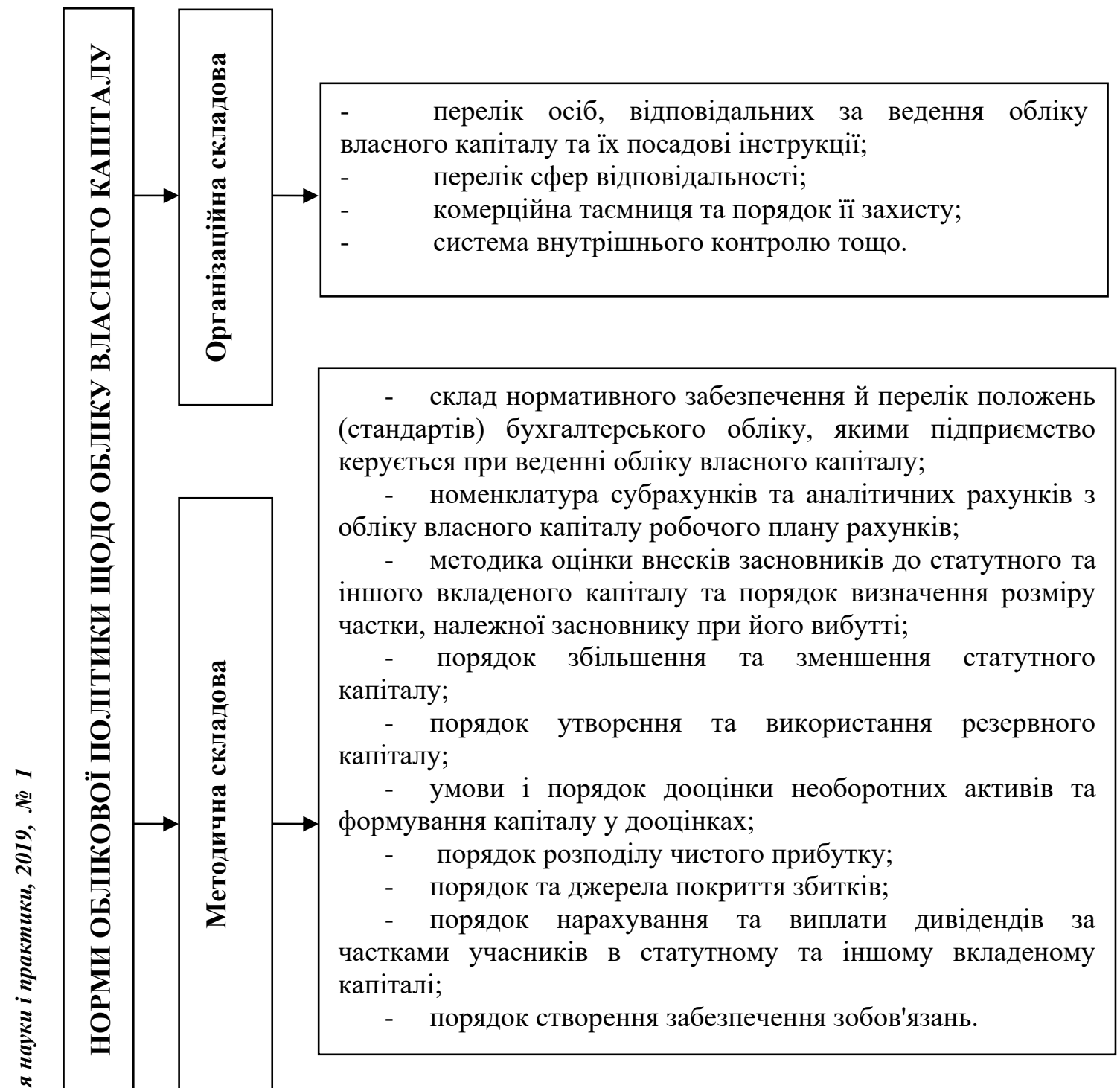

\section{Рис. 1. Пропоновані норми облікової політики щодо власного капіталу підприємства}

Джерело: сформовано автором

- первинні документи з обліку власного капіталу і графік їх документування (в додатку до Наказу про облікову політику - плані-графіку документообігу);

- перелік субрахунків та аналітичних рахунків, необхідних для відображення в бухгалтерському обліку операцій з власним капіталом (в додатку до Наказу про облікову політику - робочому плані рахунків).

Робочі плани рахунків підприємств практично повністю дублюють зміст типового плану рахунків, враховуючи незначні додаткові розрізи аналітичних ознак, зумовлених особливостями діяльності суб'єкта господарювання.

Така практика не сприяє раціональній організації бухгалтерського обліку на підприємствах.

Пропонуємо для практичного застосування товариствами 3 обмеженою відповідальністю запровадити розділ наказу про облікову політику, що регулюватиме облік власного капіталу (табл. 3). 
Таблиия 3

Пропонована структура розділу наказу про облікову політику щодо обліку власного капіталу для товариства з обмеженою відповідальністю

\begin{tabular}{|c|c|}
\hline № 3/II & Методична складова облікової політики \\
\hline 1 & Статутний капітал \\
\hline 1.1. & $\begin{array}{l}\text { Вартість вкладу кожного учасника товариства повинна бути не меншою за } \\
\text { номінальну вартість його частки. Вклад у негрошовій формі повинен мати грошову } \\
\text { оцінку, що затверджується одностайним рішенням загальних зборів учасників, у } \\
\text { яких взяли участь всі учасники товариства. }\end{array}$ \\
\hline 1.2 . & $\begin{array}{l}\text { Дивіденди виплачуються за рахунок чистого прибутку товариства, пропорційно } \\
\text { розміру часток учасників у статутному капіталі. }\end{array}$ \\
\hline 1.3 . & $\begin{array}{l}\text { Дивіденди учасникам нараховуються і виплачуються по закінченню календарного } \\
\text { року протягом першого місяця, наступного за звітним, року. Дивіденди можуть } \\
\text { виплачуватись у грошовій та негрошовій формі. }\end{array}$ \\
\hline 1.4 . & $\begin{array}{l}\text { Дивіденди учаснику, який повністю або частково не вніс свій вклад, не } \\
\text { нараховуються та не виплачуються. }\end{array}$ \\
\hline 1.5 . & $\begin{array}{l}\text { Статутний капітал збільшується (зменшується) за рішенням Загальних зборів } \\
\text { учасників. Прийняття такого рішення відбувається більш як } 75 \% \text { голосів. }\end{array}$ \\
\hline 1.6. & $\begin{array}{l}\text { Повідомлення про рішення Загальних зборів Товариства щодо зменшення } \\
\text { статутного капіталу надсилається кредиторам, чиї вимоги до товариства не } \\
\text { забезпечені заставою, гарантією чи порукою в 10-денний строк. }\end{array}$ \\
\hline 1.7. & $\begin{array}{l}\text { Збільшення статутного капіталу без додаткових вкладів здійснюється за рахунок } \\
\text { нерозподіленого прибутку. Рішення про таке збільшення статутного капіталу } \\
\text { приймають Загальні збори засновників більш ніж } 50 \% \text { голосів (якщо частки } \\
\text { засновників не змінюються) і 100\% голосів (якщо частки засновників змінюються). }\end{array}$ \\
\hline 2 & Капітал у дооцінках. \\
\hline 2.1 . & $\begin{array}{l}\text { Відносити до капіталу у дооцінках дооцінку (уцінку) необоротних активів і } \\
\text { фінансових інструментів, які відповідно до національних положень (стандартів) } \\
\text { бухгалтерського обліку відображаються у складі власного капіталу. }\end{array}$ \\
\hline 2.2. & $\begin{array}{l}\text { Проводити переоцінку об’єктів основних засобів, залишкова вартість яких } \\
\text { відрізняється від їх справедливої вартості на дату балансу більш ніж на } 8 \text { \%. }\end{array}$ \\
\hline 2.3 . & $\begin{array}{l}\text { Переоцінку об'єктів нематеріальних активів не здійснювати, } \\
\text { на відсутність активного ринку за ними. }\end{array}$ \\
\hline 2.4. & $\begin{array}{l}\text { Перевищення сум попередніх дооцінок над сумою попередніх знижень ціни } \\
\text { залишкової вартості переоціненого об'єкта основних засобів/нематеріальних } \\
\text { активів уключати до складу нерозподіленого прибутку при вибутті такого об'єкта. }\end{array}$ \\
\hline 2.5 . & $\begin{array}{l}\text { Витрати, пов’язані з поліпшенням об’єкта основних засобів, включати до первісної } \\
\text { вартості об’єкта в сумі, що перевищує } 10 \text { \% сукупної балансової вартості всіх груп } \\
\text { основних засобів, що підлягають амортизації, на початок звітного податкового року. }\end{array}$ \\
\hline 3. & Створювати резерв забезпечення: \\
\hline 3.1. & $\begin{array}{l}\text { На виплату відпусток працівникам підприємства. Величину забезпечення } \\
\text { розраховувати шляхом множення фактично нарахованої працівникам заробітної } \\
\text { плати на коефіцієнт резервування, який обчислюють як відношення річної планової } \\
\text { суми на оплату відпусток до загального річного планового фонду оплати праці. }\end{array}$ \\
\hline 3.2. & $\begin{array}{l}\text { Номенклатура робочих бухгалтерських рахунків, а також побудову аналітичних } \\
\text { рахунків з обліку власного капіталу і забезпечення зобов'язань наведена в Додатку } \\
1 \text { до цього наказу. }\end{array}$ \\
\hline 4. & Резервний капітал. \\
\hline 4.1 . & $\begin{array}{l}\text { Резервний капітал створюється за рахунок прибутку чистого прибутку. } \\
\text { Щорічні відрахування здійснюються у розмірі } 5 \% \text { чистого прибутку. } \\
\text { Відрахування здійснюються до повного формування ( } 25 \% \text { розміру статутного }\end{array}$ \\
\hline
\end{tabular}

Джерело: сформовано автором з урахуванням змін законодавства [8] 


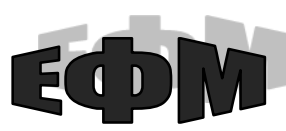

http://efm.vsau.org/

Формування такого розділу дозволить узгодити положення облікової політики та установчих документів з метою задоволення інтересів користувачів щодо обліку власного капіталу. Адже належне формування облікової політики є важливим елементом внутрішнього регулювання формування та обліку власного капіталу, сприяє підвищенню повноти та достовірності інформації про фінансовий стан підприємства.

Висновки. На основі дослідження нормативного регулювання формування та обліку власного капіталу в товариствах з обмеженою відповідальністю виявлено, що держава на макрорівні регулює лише окремі аспекти цих процесів. При цьому залишається широкий спектр варіативності в обранні організаційних та методичних прийомів обліку власного капіталу. Це, в свою чергу, надає можливість власникам товариств обирати оптимальний альтернативний варіант обліку саме для даного конкретного суб'єкта, враховуючи специфіку його діяльності. Основними внутрішніми регламентами підприємств, що врегульовують питання формування, використання та обліку власного капіталу є статут та наказ про облікову політику. Дослідження виявило недоліки у формуванні норм як статуту, так і наказу про облікову політику товариств 3 обмеженою відповідальністю щодо власного капіталу. Запропоновано зміни до зазначених внутрішніх регламентів товариств з обмеженою відповідальністю, що приведе у відповідність їх норми з нормами законодавства, зокрема 3 нормами Закону України «Про товариства 3 обмеженою та додатковою відповідальністю» від 06.02.2018 №2275-VIII та дозволить отримати повну, релевантну, неупереджену інформацію про власний капітал усім зацікавленим особам.

\section{Список використаних джерел}

1. Калетнік Г.М. Науково-теоретичні засади формування та розвитку людського капіталу в сільських територіях / Г.М. Калетнік, А.Г. Мазур // Економіка. Фінанси. Менеджмент: актуальні питання науки і практики. 2016. № 10. С.7-25.

2. Мазур В.А. Методика аналізу фінансового стану підприємства відповідно до вимог внутрішніх і зовнішніх користувачів / В.А. Мазур, О.Ф. Томчук, Ю.Ю. Браніцький // Економіка. Фінанси. Менеджмент: актуальні питання науки і практики. 2017. № 3. C.7-20.

3. Гудзенко Н.М. Звіт про власний капітал: порядок складання та шляхи удосконалення / Н.М. Гудзенко, Т.П. Горобець. [Електронний ресурс]. Режим доступу:http://www.rusnauka.com/8_NND_2010/Economics/60336.doc.htm.

4. Здирко Н.Г. Облік державної підтримки сільськогосподарських підприємств за міжнародними стандартами / Н.Г. Здирко // Глобальні та національні проблеми економіки. Електронне наукове видання. 2015. №5. С. 999-1003.

5. Камінська Т.Г. Капітал як об'єкт вартісного виміру в сучасному обліку / Т.Г. Камінська // Облік і фінанси АПК. 2010. №3. С. 33-40.

6. Коваль Л.В. Вплив облікової інформації щодо власного капіталу на прийняття управлінських рішень / Л.В. Коваль Арсенюк А. // Ефективна економіка. 2017. №6. Режим доступу: http://www.economy.nayka.com.ua/ ?op=1\&z=5632.

7. Про внесення змін до Закону України «Про бухгалтерський облік та фінансову звітність в Україні» щодо удосконалення деяких положень: Закон України від 05.10.2017 р. № 2164-VIII. 


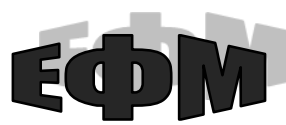

http://efm.vsau.org/

8. Про товариства 3 обмеженою та додатковою відповідальністю: Закон України від 06.02.2018 №2275-VIII.

9. Сільське господарство України за 2017 рік: статистичний збірник. К.: Державна служба статистики України, 2018. 245 с.

10. Господарський кодекс України від 16 січня 2003 року № 436-IV.

11. Національне положення (стандарт) бухгалтерського обліку 1 «Загальні вимоги до фінансової звітності», затверджене наказом Міністерства фінансів України від 07 лютого 2013 року № 73.

12. Концептуальна основа фінансової звітності від 01.09.2019 [Електронний pecypc]. Режим доступу: https://zakon.help/article/konceptualna-osnova-finansovoi-zvitnosti.

\section{References}

1. Kaletnik H.M. (2016). Naukovo-teoretychni zasady formuvannia ta rozvytku liudskoho kapitalu $\mathrm{v}$ silskykh terytoriiakh [Scientific and theoretical foundations of the formation and development of human capital in rural areas] Ekonomika. Finansy. Menedzhment: aktualni pytannia nauky i praktyky - Economy. Finances. Management: topical issues of science and practice, 10, 7-25 [in Ukrainian].

2. Mazur V.A. (2017). Metodyka analizu finansovoho stanu pidpryiemstva vidpovidno do vymoh vnutrishnikh i zovnishnikh korystuvachiv [Method of analysis of the financial condition of the company in accordance with the requirements of internal and external users] Ekonomika. Finansy. Menedzhment: aktualni pytannia nauky i praktyky - Economy. Finances. Management: topical issues of science and practice, 3, 7-20 [in Ukrainian].

3. Hudzenko N.M. \& Horobets T.P. (2010). Zvit pro vlasnyi kapital: poriadok skladannia ta shliakhy udoskonalennia [Equity statement: composition and ways of improvement]. Retrieved from: http://www.rusnauka.com/ 8_NND_2010/ Economics/ 60336.doc.htm [in Ukrainian].

4. Zdyrko N.H. Oblik derzhavnoi pidtrymky silskohospodarskykh pidpryiemstv za mizhnarodnymy standartamy [Accounting for state support of agricultural enterprises according to international standards]. Hlobalni ta natsionalni problemy ekonomiky. Elektronne naukove vydannia - Global and national problems of the economy. Electronic scientific edition, 2015, 5, 999-1003 [in Ukrainian].

5. Kaminska T.H. (2010). Kapital yak obiekt vartisnoho vymiru v suchasnomu obliku [Capital as an object of value measurement in modern accounting]. Oblik i finansy APK - Accounting and finance of agroindustrial complex, 3, 33-40 [in Ukrainian].

6. Koval L. \& Arseniuk A.V. (2017). Metodychni aspekty provedennia audytu vlasnoho kapitalu [Methodological aspects of the audit of own capital] Efektyvna ekonomika - Effective economy, 6. Retrieved from http://www. economy. nayka.com.ua/?op=1\&z=5656 [in Ukrainian].

7. Pro vnesennia zmin do Zakonu Ukrainy «Pro bukhhalterskyi oblik ta finansovu zvitnist v Ukraini» shchodo udoskonalennia deiakykh polozhen: Zakon Ukrainy vid 05.10.2017 r. № 2164-VIII [On Amendments to the Law of Ukraine "On Accounting and Financial Reporting in Ukraine" regarding the improvement of some provisions: Law of Ukraine dated October 5, 2017 №2164-VIII] [in Ukrainian].

8. Pro tovarystva $\mathrm{z}$ obmezhenoiu ta dodatkovoiu vidpovidalnistiu: Zakon Ukrainy vid 06.02.2018 №2275-VIII [About limited liability companies: Law of Ukraine dated 02.06.2018 №2275-VIII] [in Ukrainian].

9. Sil`s`ke gospodarstvo Ukrayiny` za 2017 rik: staty`sty`chny`j zbirny`k. K.: Derzhavna sluzhba staty`sty`ky`Ukrayiny`, 2018. 245 s. 
10. Gospodars`ky`j kodeks Ukrayiny` vid 16 sichnya 2003 roku \# 436-IV.

11. Natsionalne polozhennia (standart) bukhhalterskoho obliku 1 «Zahalni vymohy do finansovoi zvitnosti», zatverdzhene nakazom Ministerstva finansiv Ukrainy vid 07 liutoho 2013 roku № 73 [National Accounting Standard 1 "General Requirements for Financial Statements", approved by the order of the Ministry of Finance of Ukraine dated February 7, 2013 №73] [in Ukrainian].

12. Kontseptualna osnova finansovoi zvitnosti vid 01.09.2019 [Conceptual basis of financial reporting from 01.09.2019] Retrieved from https://zakon.help/ article/ konceptualna- osnova-finansovoi-zvitnosti/ [in Ukrainian].

\section{Відомості про автора}

ІЩЕНКО Яна Петрівна - кандидат економічних наук, доцент кафедри обліку та оподаткування в галузях економіки, Вінницький національний аграрний університет (21008, м. Вінниця, вул. Сонячна, 3, e-mail: jana_2006@ukr.net).

ISHCHENKO Yana - Candidate of Economic Sciences, Associate Professor of the Department of Accounting and Taxation in the Fields of the Economy, Vinnytsia National Agrarian University (21008, Vinnytsia, 3 Soniachna Str., e-mail: jana_2006@ukr.net).

ИЩЕНКО Яна Петровна - кандидат экономических наук, доцент кафедры учета и налогообложения в отраслях экономики, Винницкий национальный аграрный университет (21008, г. Винница, ул. Солнечная, 3, e-mail: jana_2006@ukr.net).

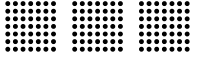

УАК 167.2: 336.27:005

\section{АНАЛІТИЧНЕ ЗАБЕЗПЕЧЕННЯ} ЗАБОРГОВАНОСТІ ПІДПРИЕМСТВА В УМОВАХ АНТИКРИЗОВОГО УПРАВЛІННЯ ${ }^{\odot}$
Т.О. МУЛИК, кандидат економічних наук, доцент, завідувач кафедри аналізу та статистики,

О.Ф. ТОМЧУК, кандидат економічних наук, доцент, доцент кафедри аналізу та статистики,

Л.I. ФЕДОРИШИНА, кандидат історичних наук, доцент, доцент кафедри аналізу та статистики, Вінницький національний аграрний університет (м. Вінниця)

Досліджено систему аналітичного забезпечення підприємства в умовах антикризового управління. Визначено підходи до розуміння сутності антикризового управління, його мети, ролі та наведено основні вимоги до формування системи антикризового управління. Встановлено, щуо система антикризового управління має

๑๑ Т.О. МУЛИК, О.Ф. ТОМЧУК, Л.І. ФЕДОРИШИНА, 2019 